$\xi=-1$

\title{
Financial Prerequisites for the Implementation of EU Direc- tives at the Railway Transport in Ukraine
}

\author{
M.O. Ieromyna ${ }^{1}$, V.V. Dykan ${ }^{2}$, K.A. Karacharova ${ }^{1}$, O.G. Kirdina ${ }^{1}$, L.B.Bilous ${ }^{2}$ \\ $I_{*}$ Ukrainian State University of Railway Transport \\ ${ }^{2}$ Kharkiv National University named by V.N. Karazin \\ *Corresponding author E-mail:maeremina1802@gmail.com
}

\begin{abstract}
The article analyzes the EU rail transport directives to be implemented in Ukraine after signing the Association Agreement between the EU and Ukraine, as well as the systematic positive and negative consequences and reservations of the implementation of the directives in the Ukrainian rail transport legislation. However, bringing of rail transport to the state declared in these directives requires significant investments including foreign ones. At the same time, the investment attractiveness of the railway industry is very low. The reason for this is the unsatisfactory state of the non-current assets, low quality of transportation, unprofitable passenger transportation which requires cross-subsidization, etc. Upgrade of the transport infrastructure should be carried out with the use of the latest energy efficient technologies. There is a need to change the management principles of the railway industry as a whole. Fulfilment of implementation conditions will trigger the attraction of investments and increase of the revenue part of the budget of Ukrzaliznytsia, which in turn will increase the competitiveness of the domestic railway.
\end{abstract}

Keywords: adaptation of the Ukrainian railways to the European standards; energy efficient technologies; financing the EU directive; implementation of EU directives on rail transport; investment attractiveness of rail transport; the competitiveness of Ukrainian railways.

\section{Introduction}

Signing the Association Agreement between Ukraine, the European Union and its member states opened up new opportunities and created new standards in various spheres of public life. But, at the same time, there was a need for new instruments for the implementation of these standards at all levels and areas of activity, starting with the updating of the regulatory framework and finishing with the modernization of production. In recent years, the need to increase the level of environmental friendliness and energy efficiency of enterprises, households, services, etc. has been actively promoted at all levels. This replaces equipment, optimizes production, and the consumption of resources is revised to more energy efficient. Railway transport is one of the most environmentally friendly modes of transport. The main railways are worn by $94 \%$, which reduces both the level of comfort of passengers and also the safety of such transportation. The attraction of domestic and foreign investments, as well as increase of railroad revenues through modernization, is a way to increase the level of comfort, safety and competitiveness of Ukrainian railways.

\section{Main Results}

The Association Agreement between the EU and Ukraine predetermines certain changes in the national legislation and strategies of the development of railway transport enterprises. In this regard, the consequences of this implementation should be systematized with the indication of positive and negative sides; these directives should be analyzed and compared with the Ukrainian regulatory legal basis and the financial capacity of the railways by harmoniz- ing them with the EU norms and standards; the financial and economic principles of implementation of the transport sector after the signing of the Association Agreement should be considered. At the same time, the modern development of the national transport complex should take into account not only the need for adaptation to the European standards, technical conditions, principles of management, etc., but also that innovations and high technologies are crucial for the formation of a new, more efficient model of management of the development of the Ukrainian road transport complex. However, the norms of the speed of goods delivery of the Ukrainian railways are not more than $400 \mathrm{~km}$ per day, that is, less than $17 \mathrm{~km} / \mathrm{h}$, and for most loads it is $8-14 \mathrm{~km} / \mathrm{h}$.

The lack of sustainable financing for transport development and insufficient maintenance of infrastructure facilities in recent decades have led to large-scale wear (about 94\%) of fixed assets of transport infrastructure. This means that only $6 \%$ of the car would have been to ride. In order to meet the conditions for scientific and technical cooperation with EU countries, the Ukrainian railways need upgrading, modernizing and purchasing new rolling stock.

But replenishment of the sinking fund is carried out on the account of the reimbursement of the original and final value of non-current assets. At the same time, the amount of compensation is directly proportional to the value of funds. Thus, the more new property there is, the more efficiently the sinking fund is replenished, due to which the fixed assets of the transport infrastructure can be reconditioned. Consequently, railway managers need to find a source of financing only once, and further upgrades, modernization and acquisition of new fixed assets should be carried out regularly, if necessary, but with significantly lower additional investment under reasonable management. 
In our country, almost $80 \%$ of the main passenger traffic was formed during the Soviet Union. For a long time there was no investing and rolling stock renewal.

But today Ukrzaliznytsya is constantly working on updating the rolling stock. Purchases of new cars are being made and the ones that are currently operating their resource are being modernized During the period of 2010-2016, only day-trip electric trains INTERSITY + were purchased, other types of passenger cars were not purchased.

In 2017, Ukrzaliznytsya purchased 50 passenger and cargo units, purchasing 54 more new cars is planned. But modernization of old cars takes place more than the purchase of new ones, but a large number of rolling stock should be replaced in order to prevent further reduction and elimination of the fleet of passenger cars.

Also, in recent years a lot of repairs and modernization have been performed for comfortable transportation: devices have been installed to maintain the average temperature mode of supply of wagons, equipment of 64 stations has been equipped with modern power supply systems that support the required temperature in passenger cars.

As for improving the comfort of the passengers - there is a need to change the trains' schedule. It is desirable for this period of time to be 20-30 minutes to reduce the waiting time at stations between trains for transplantation. It is possible to purchase tickets with a transfer online.

We believe that it is necessary to develop the routes of passenger trains across the country in order to form a comfortable, fast and reliable connection between separate regions. It is also necessary to create new international routes.

Another of the basic conditions for implementation is the formation of a new interchange point in Mukachevo, which will enable the transition from a broad gauge to a narrow one to a foreign train and go to Europe. In the near future, this item is needed in Mukachevo to reach Budapest, then Romania, Poland, Slovakia and other countries.

But all this requires significant funding, and passenger transportation is unprofitable, it is a worldwide practice. So 10 million yards of damage was only in 2017, as a result of which it is necessary to use cross-subsidization, that is to supplement the passenger transportation by cargo business. That was always the case. In connection with the increase of the cost of components of transportation with every year, losses increase. Immediate revision of transportation tariffs is required. At the present time, Ukrzaliznytsya, at the expense of profits from cargo transportation and other types of its activities, carries out the financing of passenger-transport services. It does not receive financing from the state or other investors.

In accordance with the legislation of Ukraine regulating the activity of railway transport, interregional transportation should be financed from the state budget, suburban transportation should be financed by local budgets. According to the above, due to insufficient financing, investments in other types of activities in this direction have been decreased. Local budgets do not finance privileged transportation, and the funds return of these transfers in the average account amounts to $8-9 \%$.

If this problem was solved, one more source of financing for the implementation of the EU directives in the railway transport of our country would be found. Thus, there is a need to appeal to the government with a proposal to monetize privileged transportation by Ukrzaliznytsya

The Intercity + and international trains have a fairly high profitability, so replacing them to new rolling stock should make passenger transportation also profitable and cost-effective.

In order to solve the financial problems of railway transport, it is necessary to increase tariffs for passenger transportation. And if the state compensates for the cost of travel to privileged categories, it will lead to zero profitability and costs will be paid.

As for freight, they are carried out at a considerably expedient pace than the passenger ones. In the financial plan of 2018, there is no increase in tariffs. Nowadays Ukrzaliznytsya is no longer a monopolist on the market of cars, its total share in this market is less than $30 \%$. There were other operators, powerful enough. UZ as a powerful player in this market sets the price for wagons that are its property and earns the lease of this type of rolling stock.

By December 2017, there was a state regulation in this area. The tariff for use was 124 hryvnia per car, while on the market this value was 800 hryvnia. Today, the first stage of deregulation has been carried out, that is, the formulation of pricing has been developed. From February 19, 2018, a deregulated component already operates. This makes it possible to earn from mediators, the revenues amounted to over 300 million hryvnia for the first month At the second stage - the sale at open electronic auctions will take place. Contracts for carriage have already been signed by more than 15 thousand companies, which will be able to take part in the electronic auction and get a car at a market price, this should reduce the prices for wagons. Before, sometimes an artificial deficit was created for cars.

Foreign wagons, when the price is open, have to go here to a much greater extent. And this should eliminate the possibility of earning money from the state-owned company Ukrzaliznytsya. Gradually carriage business becomes profitable. It is profitable for investors to buy a car and to receive a profit from transportation.

It is also necessary to increase the optimization of costs, resulting in increased financial result, for example, UZ spends huge funds on the maintenance of rooms that are almost empty, that is, they are not used and do not bring profit or benefit.

In this case, you need a partnership with the state. In Europe, such a practice has long existed, for example, when individuals are prompted to get a concession facility, have the opportunity to rebuild it, but that the campaign should have received profits from these areas, whether from shopping or entertainment venues.

The Association Agreement between Ukraine and the European Union dated September 16, 2014 [1] became the starting point for global changes in the Ukrainian economy, in particular, in the transport sector in the railway transport. The above document provides for the implementation of 8 directives and 4 regulations, namely Regulation (EC) No. 1371/2007 of the European Parliament and of the Council of 23 October 2007 on the rail passengers rights and obligations [2] (Annex XXXII to Chapter 7 "Transport" section 5 "Economic and Industrial Cooperation"), which is part of the third railway package adopted by the EU in 2007. This regulation outlines the need to upgrade the European railways through the improvement of railway transport services, the regulation of user rights and increase in share rail transport in comparison with other modes of transport.

On the one hand, the necessary actions should lead to ensuring the competitiveness of Ukraine's railway transport, improving the quality of its services, which will attract potential customers and increase the revenue and profits of the railway industry. It should also be noted that this will allow not only to expand the market of transport services for passengers but also allow enterprises in other sectors (engineering, power supply and communication, enterprises of the electrical industry, etc.) to move to a qualitatively new level of production, and also should be a motive to enhance their activity.

But on the other hand, in accordance with Annex I of the Association Agreement, the introduction of basic import prices for the supply of goods from the EC of the Group of Economic Classification Class 86 (group 86 - railway or tram locomotives, rolling stock and parts of them, road equipment and devices for railways or tramways and their parts; mechanical (including electromechanical) signalling equipment of all kinds), the basic import rate for the supply of goods from this group from the EU to Ukraine is zero.

That is, by signing the Association Agreement with the EU, we are opening the way to our market for the European manufacturer of rolling stock of railway transport, without receiving any income from it without completely protecting our own [3].

Also, Ukrainian railways are lagging behind Western European parameters for speeds, which will increase the opportunity to keep leading positions in the field of passenger and freight transporta- 
tion for Ukrzaliznytsya. The main problems at the same time are the radical increase of the technical level of the infrastructure of the railway, the organization of production of high-speed rolling stock and other railway equipment, the creation of new computer systems, energy transfer, information, development of new materials, which couses the need of not only transport development, but also other branches of the economy [3].

Creation of an energy efficient complex in the field of transportation activity is aimed at minimizing the share of fuel and energy component in the cost of transport and logistics services, reducing costs and losses in the implementation of the main activities, improving the productivity of employees of the company.

This requires the further development of train management in energy optimal schedules, increasing the energy efficiency of rolling stock, infrastructure, traction network and stationary power engineering, the use of new innovative materials, more accurate means of accounting for fuel and energy inputs at the traction rolling stock with the transfer of information on the consumption of fuel and energy resources in an automated mode in the corresponding information systems without the participation of the driver.

Development of modern information and control systems, technologies for transfer and accumulation of energy, development of alternative energy sources, couses the improvement of the system for development and search of energy saving solutions and energy-efficient technical facilities of PC "Ukrzaliznytsya", their approbation and introduction into industrial operation at the reduction of the duration of each stages of the innovation process without loss of quality.

In order to reduce operating costs while simultaneously reducing the negative impact on the environment, it is necessary to further develop scientific and technological bases for expanding the introduction of new types of energy for traction of trains: gas turbines and gas diesel locomotives, the use of new types of synthetic fuel and lubricants.

It needs development of regulatory documents for the expansion of the use of alternative sources of energy in PC "Ukrzaliznytsya" gas fuel cells, wind and gas turbines, photoelectric batteries, pressure generators.

Improvement of the system of technical requirements for products intended for the needs of PC Ukrzaliznytsya of technical and technological products should be made taking into account the provision of energy efficiency and the possibility of its connection to a single power management and energy saving network.

By means of railway transport mass transportation of goods and passenger transportation are realized. This type of transport is the most ecologically clean in the transport complex of the state. The percentage of the negative impact of the railway industry in the total volume of environmental pollution on the national scale is: 0.72 - emissions into the atmosphere from stationary sources; 1.00 - from mobile sources and 0.09 - discharge of sewage into rivers and lakes; 0.08 - formation of waste products.

For the formation of railways, less money is need than for other transport systems. Well-organized directions have investment, land and environmental benefits. Railway transportation is more energy-efficient than automobile and environmentally friendly Rolling stocks have a low emission per tonne-kilometre or passenger-kilometre. This type of transport is more efficient than any other.

In many states, the railways are electrified. This special feature allows you to reduce emissions at times that are associated with railway transport. For the construction of railways, you need a smaller land corridor than for the building of highways. For the construction of freight lanes, small bends and curves are required as opposed to motorways. The impact on the environment and land-use is scarce. Thus, the length of the ways in a certain area increases. Calculations per kilometer of the way will require fewer investments when laying railways. To compare car and water transport with railways irrutionally.
The railway land corridor is environmentally friendly in many ways: it is located on a porous basis and has no significant impact on the water and drains next to it. Automobile transport brings much more damage.

Low-use routes are economically inefficient. Railways with a minimum load on the axle are less energy-efficient than the highway. This is due to the fact that freight wagons have a lot of weight. High-speed trains with small loads are less productive than airplanes and cars.

Environmental efficiency and benefits depend on the organization of the railway system and acceptable design. Such requirements apply to other types of transport.

Sectoral issues of cooperation in the field of environmental protection in the Agreement are enshrined in Chapter 6 "Environment" of Section V "Economic and Industrial Cooperation". For Ukraine, implementation of the EU environmental legislation takes place within eight sectors.

1 Environmental management and integration of environmental policy into other sectoral policies

2 . The quality of atmospheric air

3. Management of waste and resources

4. Water quality and water management, including the marine environment

5. Nature conservation

6. Industrial pollution and man-made threats

7. Climate change and protection of the ozone layer

8. Genetically modified organisms

Since environmental management tools and the integration of ecological policies penetrate almost all other sectoral policies (transport, energy, agriculture, tourism, industry, etc.), they are called cross-cutting or horizontal.

The relevant sector of EU environmental law is called the mountain-horizontal. Horizontal environmental law of the EU is presented by 5 directives.

The Association list includes four of them:

-2003/4 / EC on access to information;

- 2001/42 / EC on Strategic Environmental Assessment (SEA);

- 2003/35 / EC on public participation;

- 2011/92 / EC on Environmental Impact Assessment (EIA).

The most burdensome with the economic point of view for industrial enterprises, areas of production and transport are the Strategic Environmental Assessment (SEA) and on Environmental Impact Assessment (EIA) [5].

They relate to the assessment of the environmental consequences of public and private projects that are likely to have a significant impact on the environment and establish the rules for carrying out the Environmental Impact Assessment (EIA) 2011/92 / EC

EIA is implemented for all projects mentioned that are considered as having significant environmental impacts and require EIAs (eg, nuclear power stations, long distance railways, highways, airports, etc.)

The SEA Directive applies to a wide range of state plans and programs (eg land use, transport, energy, waste, agriculture, etc.). These are plans and programs that are prepared or adopted by the authorities at the national, regional or local level in accordance with the requirements of legislative, regulatory or administrative acts.

Directive 91/440/EC is the first directive of the European Commission in the rail sector, but since it was not very feasible, as evidenced by the relatively small number of new operators and new types of services presented on the market, four regulatory packages were approved measures in the field of rail transport "in 2001, 2004, 2007 and 2016.

In Ukraine, a number of legislative acts have been adopted, and the transport reform has begun, the results of which you are talking too early.

At the same time, each of the EU countries has its own approaches to establishing national regulatory bodies, for example in Italy, the role of the Ministry of Transport has been transformed, and railway authorities have been established. However, in spite of the 
formal incorporation by the states of the distribution of railway operators, the railway industry is still largely based on state-owned companies.

In a study of railway transport in the European Region, for the report at the Internal Transport Committee, the implications of rail reform and the impact of reform on efficiency indicators for reducing costs and productivity, price levels, customer satisfaction and service quality were studied. Data on countries that began to implement state contracts for the services on the basis of competitive tendering indicate that such practices may contribute to lower operating costs [6].

As part of the energy and resource conservation measures, it would be advisable to carry out energy-efficient measures at stations and to switch to autonomous lighting systems by obtaining electronic energy by recycling the energy of the trains or using "smart" floors and turnstiles that will accumulate energy from the movement of passenger flows and transform it into electricity. In addition, it is expedient to replace traditional fuel with more economical ones and to create less emissions into the atmosphere.

Since the rail industry is unprofitable in most European countries, each country is trying to maximize its profits and reduce its industry costs. However, foreign railways also aim at simultaneously modernization of rolling stock and passenger stations.

Since January 2017, the Dutch electric trains of the national rail company NS are equipped with wind power. Each day, the company carries about 600,000 people, and the company conducts about 5500 train transfers a day. The work of one windmill for an hour can provide a train with energy for $200 \mathrm{~km}$ [7].

A leading company like Toshiba promotes efficiency and energysaving in the various equipment and systems for rolling stock that it develops. Environmentally friendly locomotives and rolling stock systems are promoted by limiting the power consumption amount and energy loss in such systems as the Automatic Train Operation (ATO) system that makes operation with limited energy consumption possible; the train control and monitoring system that monitors and controls the operation of rolling stock electrical equipment; the power system that uses a high efficiency Permanent Magnet Synchronous Motor (PMSM); as well as such things as the air conditioning system, the lighting system and the energy storage applications system. [8].

Except such expensive and large-scale ways, there is also a number of simpler methods of energy conservation and production. So in Spain, the passenger floor consists of special plates that convert the energy of the human passage to the electric, which is used at the stations. And in India there is a replacement of ordinary lamps on LED lighting, in 2018, plans to transfer to this type of lighting all stations in the country.

Also, under the contract with Alstom (France), Indian railroad will purchase 800 electric locomotives, 795 of which will be manufactured in India in 2018 and 2028. The first French locomotives will arrive in the country in 2018.

Also on the roofs of the platform are solar panels with a power of $4750 \mathrm{~kW}$ or $4.7 \mathrm{MW}$ of electricity. The installation of panels began in 2015 and is scheduled to take place by 2025 .

In addition, such solar panels are also installed on trains. In July 2017, were launched trains with electric-powered diesel-electric power stations. The train was equipped with 16 solar panels, each of which produced $300 \mathrm{~W}$ of energy. The train has spare capacity and can operate on battery for at least 72 hours.

Another way of environmentalization the Indian Railways is biotoilets. Biodisertatory toilets split solid waste into carbon-coke methane and water. The Railways plan to install bio-toilets will help in the long run, as the waste coming out of trains, corrodes tracks and sleepers, requires more than regular maintenance work. Waste is also a terrible inconvenience for people living near railway lines, and such waste can pollute groundwater [9].

Therefore, there are many ways not only to save energy but also to generate energy. In addition, such measures save money on the railways. The Ukrainian railways have a significant potential for development and modernization, it remains only to choose ways and means.

\section{Conclusions}

By signing the Association Agreement, Ukraine has assumed the responsibility to comply with all additional directives and standards and has opened the market for imported goods and services, which usually, of lower price and higher quality. Railway stations in Europe are faster and more up-to-date than the domestic ones. However, the Ukrainian railways are a natural monopoly, which makes it possible to develop and modernize, temporarily safeguarding themselves from being squeezed out of the market. Attracting investments and increasing the revenue part of the railway budget will increase the competitiveness of domestic railways. Using the worldwide tendency towards environmental friendliness and energy conservation, the railways will be able to reduce the cost of electric energy and also sell excess energy. In addition, a number of modernizations will reduce the level of wear of rolling stock.

All these developments and proposals should improve the financial condition of Ukrainian railways and accelerate the implementation of the EU directive on railway transport.

But for today, the own funds to complete the reformation of the Ukrainian transport industry and full compliance with the EU railways are insufficient. Therefore, most of the investment funds to improve infrastructure are expected from external sources, mainly from international financial institutions, private investors and public-private partnership projects. It is the creation of a favourable investment climate is a priority task of public administration and regulation, which is ensured by the perfect legislative framework [4].

\section{References}

[1] Uhoda pro asotsiatsiyu mizh Ukrayinoyu ta Yevropeyskym Soyuzom vid 16 veresnya 2014 roku [Electronic resource]. - Access mode:.//

http://www.kmu.gov.ua/control/uk/publish/article?art_id=24838763.

[2] Rehlament № 1371 Yevropeyskoho Parlamentu i Rady vid 23 zhovtnya 2007 roku Pro prava obovyazky pasazhyriv zaliznychnoho transportu // Official Journal of the European Union, 3/12/2007.

[3] Nykyforuk O. Implementatsiya dyrektyv YES shchodo zaliznychnoho transportu v zakonodavstvo Ukrayiny: pozytyvni ta nehatyvni naslidky [Tekst] / O Nykyforuk // Ekonomist. - 2013. - № 10. - S. $15-20$.

[4] Natsionalna transportna stratehiya Ukrayiny na period do 2030 roku, available online: //:http://search.ligazakon.ua., last visit: 15.06.2018.

[5] Upravlinnya dovkillyam ta intehratsiya ekolohichnoyi polityky do inshykh haluzevykh polityk: korotkyy opys Dyrektyv YES ta hrafiku yikh vprovadzhenny, available online:

[6] http://www.if.gov.ua/files/uploads/Upravlinnya_brochure_final.pdf, last visit: 15.06 .2018

[7] Dyrektyva Rady 95/18/YEES "Shchodo zaliznychnykh pidpryyemstv", available online: // http://zakon5.rada.gov.ua/laws/show/994_952, last visit: 16.06.2018.

[8] Dutch electric trains become $100 \%$ powered by wind energy, available online: https://www.theguardian.com/world/2017/jan/10/dutch-trains-100percent-wind-powered-ns, last visit: 15.06.2018

[9] Toshiba, available online: // http://www.toshiba.com/tai/, last visit: 16.06 .2018

[10] 5 Ways the Railways Went Green, Efficient and Sustainable in 2017, available online: https://www.thebetterindia.com/125437/indian-railwayssustainable-measures-2017/, last visit: 14.06.2018 